\title{
LEXICAL MEANS OF VERBALIZATION \\ OF THE CONCEPTOSPHERE OF THE SACRED \\ IN THE POETIC IDIODYSTLE OF D. KREMEN
}

\section{Viktoriia Badenkova ${ }^{1}$ \\ Iryna Korniienko ${ }^{2}$}

DOI: https://doi.org/10.30525/978-9934-26-069-8-1

Abstract. The article is devoted to the isolation and analysis in the poetic texts of D. Kremen, groups sacred concepts, microconceptospheres, the discovery of conceptual meanings in nature which clearly feels the spiritual, linguistic and cultural and individual-authorial components. The relevance of the chosen topic is due to the increasing attention of linguists, on the one hand, to the problems of linguoculturology and linguoconceptology, on the other - to the set concepts filled with religious, sacred meaning in general. The aim of the article is to trace how in the modern scientific paradigm one of the concepts «sacred» is interpreted, connected with the thematic concept of the conceptosphere of the sacred; demonstrate new trends in the implementation of the conceptosphere sacred, whose representatives are concepts to denote God and all that is holy in the understanding of the Divine, to identify by verbalization of microconceptospheres «biblical characters», «biblical loci», «church organization and cult», «sacred-chthonic beings».

The subject of research is LEXICAL MEANS OF VERBALIZATION OF THE CONCEPTOSPHERE OF THE SACRED in poetic texts. The object is the microconceptosphere in the realization of the conceptosphere of the sacred in the poetic idiosyncrasy of D. Kremen. The methodological basis is the basic provisions of linguoconceptology, in particular the problems of interaction between language and culture. Research methods: the method of continuous sampling, which is used to collect the actual material; descriptive method, which allowed to analyze the results in a

\footnotetext{
${ }^{1}$ Candidate of Philological Sciences, Associate Professor of the Ukrainian Language and Literature Department, V.O. Sukhomlynskyi Mykolaiv National University, Ukraine

${ }^{2}$ Candidate of Philological Sciences,

Associate Professor of the Ukrainian Language and Literature Department, V.O. Sukhomlynskyi Mykolaiv National University, Ukraine
}

(C) Viktoriia Badenkova, Iryna Korniienko 
certain aspects; method of contextual and interpretive analysis associated with decoding units of secondary nomination, identification of symbolic and metaphorical and individual-authorial meanings and functional-semantic load. It was found that in the poetic idiostyle of D. Kremen the dominant of theonyms in the poetic idiostyle of D. Kremen is one of the most important cultural universals, the basis of all world religions is God. From the point of view of linguocognitology, the conceptual sphere, the conceptual image of «God», is a multifaceted, multifunctional, hierarchical structure, which is realized by multilingual connections and oppositions. The analysis of the isolated units shows that in the concept is dominated by meanings relevant to the Christian scenario, but also recorded in relation to certain pagan and ancient notions of the supreme deity. Nuclear concepts-images «Jesus Christ», "Virgin Mary» in the studied texts are characterized by a clear syncretism, due to the intersection of the manifested in its structure biblical and mythopoetic meanings. Linguistic means are singled out and characterized, which reveal both its traditional canonicity and symbolicmetaphorical representation in D. Kremen's poetic idiosyncrasy.

The specificity of the linguistic representation of the concept is represented by the actual poetic semantic individual-authorial and expressive-pictorial properties in poetic speech.against the background of preserving the traditionally established means of its verbalization. The concept of God and other specified conceptual quantities are represented in the language through the corresponding tokens by a wide range of names of different linguistic nature and stylistic specificity, used with direct and figurative meaning, synonyms, paraphrases, etc.

\section{Introduction}

In the last years of the XX century - at the beginning of the XXI century research topics, focused on the ideas of the Ukrainian national revival and stimulation of cultural and spiritual life, in particular the study of the sacredmythopoetic sphere, until recently removed from the cultural discourse, became more active.

The concept of the sacred is the object of research in various fields of human activity (philosophy, religion, culturology, literature), but its interpretation is ambiguous. In the "Dictionary of Religious Studies" we find the following definition: «Сакральне наділене божою 
благодаттю. Таким є релігійна віра, таӥнства, иерква, особи, зведені в священницький сан, речі і дії, що відносяться до релігійного культу. Сакральне, на відміну від мирського, є релігійно санкиіонованим» [20, p. 289]. V. Shevchenko gives a broader interpretation: «Сакральне 1. Надприродні істоти, якіє об'єктом поклоніння в певному релігійному культі. 2. Релігійні иінності - віросповідання, віровчення, таїнства, церква. 3. Сукупність предметів, осіб, дій, текстів, які входять в систему релігійного культу. Інша назва - священне» [23, p. 313].

The meaning of the sacred is revealed in relation to the profane, because it differs from ordinary things, concepts. The author of the book "Sacred and Secular" M. Eliade proposed to study the sacrum in the axiological paradigm "sacrum-profanum", noting that «священне $і$ світське - це два способи буття в світі, дві ситуаиіі існування, які приймає людина в ході історії. Ці способи буття в світі становлять інтерес не тільки для історії та соиіологї̈, не тільки якоб'єкт історичних, соціологічних та етнографічних досліджень. Адже священний і світський способи існування свідчать про різнищю статусу людини в Космосі. Тому вони иікавлять $і$ філософів, $і$ тих дослідників, які прагнуть пізнати можливі масштаби людського існування» [6, p. 257].

According to the Polish researcher Stefan Savitsky, the sacred includes everything that is connected with the religious orientation of the human person to something mystical, supernatural, to something that has a halo of holiness [24, p. 14]. The genesis and development of the sacred in Ukrainian literature are also discussed in in Igor Nabytovych's thorough monograph "The Universe of Sacrament in Fiction (From Modernism to Postmodernism)" [17]. («Універсум Sacruḿy в художній прозі (Від модернізму до постмодернізму)» [17]).

A notable feature of modern linguistics is the study of the sacred in the system of linguocognitive, linguocultural, comparative-historical paradigms. A number of works by Ukrainian linguists are devoted to the analysis of sacredisms in the functional-structural (I. Bocharova, Y. Brailko, N. Sologub) and linguocognitive (linguoculturological) aspects (T. Vilchynska, N. Mekh, P. Matskiv, A. Sirant, M. Skab and others). Some sacred concepts have attracted the attention of such modern linguists as T. Radzievska, L. Panova, P. Matskiv, O. Yasinovska. Thus, M. Skab in a number of works analyzed the process of conceptualization of the sacred 
sphere in the Ukrainian language on the material of the concept of SOUL [22]. T. Vilchynska generalized the views of scientists on the conceptosphere of the sacred in the modern scientific paradigm [4], believing that the basic unit of linguistic-conceptual picture of the world, objectified in poetic texts, is the concept-image, which «становить собою функиіональноструктурну домінанту художньої картини світу, виявляючи індивідуальне світобачення, світовідчуття автора як носія певної національної культури» and helps to reveal «розвиток індивідуальноавторських картин світу та простежувати креативну роль мовної особистості письменника в цьому процесі» [5, p. 11].

Studies of the linguistic and cultural specifics of concepts that form in particular the microconceptosphere "holiness" allow to learn more about ethnopsychological principles of national worldview, to model the linguistic and conceptual picture of the world of the Ukrainian people, for whom faith in God is a primordial mental feature [7, p. 117].

The purpose of our research is to demonstrate the emergence of new tendencies in the poetic idiostyle of D. Kremen in the realization of the conceptosphere of the sacred against the background of preserving the traditionally established means of its verbalization.

As D. Kremen's creative work contains a significant number of sacred concepts, such as a rich anthroponymicon (according to biblical history), historical and biblical toponymic names, numerous Church Slavonicisms, appeals to the Lord God, Christ, the Mother of God, apostles, etc., this sphere could not stay out of researchers' attention. Religious and philosophical motives, in general, the issue of the sacred in the poetic work of the artist studied primarily literary critics. Thus, the subject of Inna Bereza's scientific interests became the iconic sacred images of D. Kremen's poetic work and the manifestation of the sacredness of poetry in painting [2]. Taras Kremin through the original reception of God with its metalogical direction, inherent in the literary era of the last decades of the twentieth century, provides an understanding of certain models of poetic pursuits of God, presented in the author's iconic literary texts [15]. Yulia Nabok-Babenko, analyzing biblical motifs and images in the poetic works of the collection "Pectoral" noted that D. Kremin models motifs and images from the Holy Scriptures on the present or a certain historical background, enriching them with semantic nuances and current interpretations [18]. 


\section{The concept of the sacred as an object of study}

Since the sacred as a special conceptosphere can be considered as a «certain area of religious knowledge» and as a «set of concepts filled with religious meaning» [4, p. 154], we note that in idiosyncrasy it covers a set of thematically similar concepts, words, images, symbols or the conceptual basis of the appropriate discourse, the language of the writer, but can also relate to a particular concept in its relationships and dependencies. In view of this, the material collected and analyzed in our work allowed us to model a conceptosphere that encompasses a set of concepts, each of which has its own sacred meaning and consists of the following microconceptospheres:

1) «general religious characters», among which we highlight a) the name of the Heavenly Hierarchy: Jesus Christ, the Holy Trinity, and so on. b) concepts-images of prophets: Elijah, Moses, etc.; c) various religious characters: the prophet, Cain, etc.; 2) «biblical loci»: heaven, hell, Eden; 3) «church organization and cult»: a) the names of religious buildings and their parts: church, altar, God's temple; b) church hierarchy: pastor, priest; c) names connected with church-ritual activity: cross, incense; d) names of church services sacraments, rites: christening, prayer etc. e) liturgical books and their parts: the Bible, the Book of Books; 4) «sacred time»: Christmas, Annunciation, etc.; 5) established names associated with biblical motifs: the Way of the Cross, the crown of thorns, etc.; 6) moral and ethical names: good, love, sin, etc.; 7) sacred-chthonic names: devil, satan, etc.

A special group in the system of concepts are words like amen, hallelujah, hosanna, which, according to T. Vilchynska, perform not only text-forming functions, but also act as a kind of structural factors in poetic texts [5, p. 7].

All these conceptual values are represented in the language through the corresponding lexemes in a wide range of names used with direct and figurative meaning, synonyms, paraphrases, etc. Lexemes for their designation are actively used in various syntagms, they are also a derivational basis for the creation of derivative verbalizers belonging to different parts of speech.

\section{Lexical realization of the key concept of God}

The dominant of theonyms in D. Kremen's poetic idiosyncrasy is God, Jesus Christ. The concept of God is one of the most important cultural universals, the basis of all world religions, which unites in the system of 
linguistic coordinates and oppositions ontological, mythological, religious, spiritual constants of the individual and society. It is part of various pictures of the world: secular and religious - and is a segment of the Ukrainian language picture of the world. In the secular picture of the world in the conceptual sphere of culture, this concept has a religious and ethical nature, reflects the features of the national mentality, represented in knowledge, beliefs, customs, religion. From the point of view of linguocognitology, the conceptosphere of God is a multifaceted, multifunctional, hierarchical structure, which is realized by multilingual connections and oppositions.

In the poetry of Dmitry Kremen we fix the following conceptual meanings:

- God is the Creator: «той, який створив світ та керує ним ілюдьми», «Бог є Творием світу і Промислителем Всесвіту» [3, p. 96]. This is what determines the sacred power endowed with human characteristics, the God of heaven and earth, all visible and invisible: Та він повзучим говорити смів, / Що Бог створив і гадину, і птаха... [9, p. 355-356]. The poet points to this conceptual meaning indirectly: Та сім днів Сотворіння - / Труд до сьомого поту [9, p. 222].

- God is Almighty: Ми люде ци богове, ми велетні ци гноми... / Рівнятися із Господом - негоже: / Я тінь Твоя, / І я в твоїм сліду... («Бенефіс на Голготі»);

- God-Savior: Мій Боже верховний, рятуй над од мору... [9, p. 317];

- God-Judge: Усім - по таланту. / Усім - як судив Господь [9, p. 135];

- God-Light: Він у сяйві постав перед нами; Уночі до мене прийшов Бог - сяючий, як сад. У білому, / Як собор... / Сад упав на коліна. / І я на коліна упав, наче сад [9, p. 299].

- The adjective white, along with the meaning of color, acquires the connotative meaning "the one who shines", because the Lord, called in the Holy Scriptures the sun, is the source of all light, goodness and bliss [3, p. 666]. The God of Light in heathen religions, as a rule, lived in a shining sky or on a sacred mountain illuminated by the sun, and was treated as a source of knowledge, especially moral: І шепнув мені тихо: "Не бійся!» / Бог любові, поганський мій бог, / Він у сяйві постав перед нами / I не стало на світі зими...[10, р. 355].

Polysemantic conceptualization of God is realized in the form of attributing to him semantic roles within the conceptual features of GOD 
is SUCH, which contain a general sacred and poetic concept: «Той, який $\epsilon$ уособленням величі, всемогутності, всюдисущності»: Він у сяйві постав перед нами/ I не стало на світі зими; I співають осанну невисохлі ріки. / Отче наш на землі і на небі [9, р. 304]; «Той, який оберігає, допомагає»: Не кинув Бог, не посміявся ворог [14, р. 58]; «Той, який обдаровує і наділяє благами»: А вдвох ми -ие родина. / Все тобі, щзо нам дарує Бог [13, p. 71]. The very concept of God is genetically related to the definitions of «good», «rich», ie the master of many goods and the one who bestows them; «Той, який є втіленням святості, доброти, милосердя»: Чи у Господа милість така є, / Як вечірня пречиста зоря? [14, p. 39]; «Той, що є джерелом радості, прославлення»: Слава Господу й небу. / Що зібрало колядників Свято Різдва [9, р. 133]; «Той, який $\epsilon$ об'єктом віри і поклоніння»: Уночі до мене прийшов Бог - сяючий, як сад... / Сад упав на коліна. / I я на коліна упав, наче сад [9, p. 299].

For the poet, «turning to God has become an obvious way of finding oneself in difficult life conflicts, and Christian ethics - a measure of spiritual worldview, the continent of further artistic development» [15, p. 23], the source of individual-author meanings: Господи / молюсь тобі сльозою... [12, p. 34].

The periphery of the described concept is a set of occasional associations - GOD (agent) acts with someone (agent), GOD (agent) acts so (way). Thus, a harmony of relations is established between God and people: Людина хоче знати те, щчо й Бог; Небесне $i$ земне. Земне й Небесне. / Іще наш украӥнський бог воскресне, / Тоді, як ми воскреснемо зі сну [13, p. 62]. An unusual perception of the world is modulated, in which God is not only a Teacher, Mentor, Counselor for the poet, but his equal partner: (in addressing to the poet-brothers) Люди - глина співуча. / Я знаю, кому / їх людьми і належить ліпити... [9, р. 329]; Не я пишу це мною пише Бог [10, p. 49]. Interpretations built on a metaphorical basis are accompanied by the actualization of certain properties. The feeling of unlimited freedom is given by youth, that «юнацький запал $і$ відкритість намірів, котрі допомагають його поколінню не тільки вистояти, але й побудувати ідеальний, де в чому утопічний світ» [15, p. 25]: Ми були красиві, як боги... [1, p. 103].

Poetic texts show a clear ambivalence of the described concept, filled with a number of individual-author conceptual meanings: on the one hand, God defends, protects the innocent, helps, this is the one who is prayed for 
salvation because it is associated with justice, and on the other - God - it is "the one who punishes; formidable force": $О$, не спали цю землю, грізний Боже, / Ще є тут украйнці, не хохли [9, p. 256]. In the fragment «The one, who gifts» the poet figuratively unfolds the common language meanings, specifying them with certain components with a positive connotation endows with silver snow, happiness, Christmas, honey, wine, love, joy and more. But God is also represented - «He who performs a destructive function»: Потопами, війною, ураганами / Благословив Господь ичей бідний край [9, р. 287].

The master of the word sacred (sacred) fascinates with its unusualness, unusualness, importance, ability to evoke admiration, joy, fear and other strong emotions: Господи, як воно близько до щастя [9, p. 212]. In many reactions it is possible to learn constant expressions - appeals-exclamations and language clichés: Як там скрипка виспівує, Боже [14, p. 59]. His appeals to God also express a desire to hear the answer to urgent social problems and the question of why he left the world without his caress: Господи / молюсь тобі сльозою / вирви із епохи мезозою / стань для нас молитвою без слів... / Під чужими ходимо богами [9, р. 237]. It is characteristic of D. Kremen's poetic idiosyncrasy that appeals to the Lord in texts often occur in combination with the conceptual image of Ukraine and the associated with it hope for a better fate and salvation: Боже, як ще не покинув нас ти, / На украӥнському вічному небі / Божому сину зорю засвіти! [9, p. 331]. The presence of such appeals in contexts reduces the meaning of the concept, erases to some extent its sacredness, and thus the concept loses its original religious meaning, shifts the reader's attention to the earthly, domestic sphere: спаси $і$ сохрани, Благословив Господь, слава богу: Ти, старенький Боже, Бога бійся: не покинь, спаси / і сохрани! [9, p. 45].

Interesting reflections on the determinism of human existence, full, on the one hand, high and sublime, on the other - mundane, are realized through a range of interesting in content and form elements of the associative-figurative series of the female body, language, steppe, garden, etc.: Жіноче тіло! Тіло - бог! [9, p. 349]. The poet interprets in a peculiar way in the poetry «All words» biblical images, which serve as a means for him to rethink eternal questions, allow to delve into the essence of important things: Слово Бога, українська мова, / Лиш у слові Бога ти жива [9, p. 236]. 
One of the main components of the author's cosmology is the individualized image of the Ukrainian god, endowed with anthropomorphic features and generalized to the level of the nationally connoted symbol: Мельник, старенький Зевес, / Крутить заржавілі зерна [12, p. 68]. The low connotations accompany the realization of the concept of God in the poetic characteristic combinations of the sacred and the everyday in certain contexts: Та до Бога летить есемеска [9, p. 167]. The expression God helps those who help themselves indicates that it is easier for a prudent person to avoid danger. In poetry it is supplemented by a new component: Береженого суджения Бог береже [9, p. 99] to enhance the expression and specification of the content.

The poet's "search for God" is expressed through the author's characteristic opposition to his / another's, realized in a number of images: украӥнський бог / Чужинський Господь [9, р. 99]; дороги, яка веде на чужину - ...веде до чужого порога. Дорога, де жде сатана - та до Вітчизни: А йшли ми - до Бога... [13, p. 23].

In the works of Dmytro Kremen, the peculiarities of the linguization of the analyzed concept-image are most clearly traced in its names (concept explicators) and religious personalities: God, Creator, Almighty, Judge, Savior, etc., which do not go beyond the usual, attested in theological texts. Not only the meanings of this concept as a Christian God are productive, but also ethnopsychological, linguistic and cultural principles of national perception and understanding of conceptual semantics, reflecting the features of national mentality, represented in knowledge, beliefs, religion components of the cultural concept. In the process of actualization, the poet often appeals to "foreign" gods: the ancient Roman Saturn, Jupiter, the gods of Greece - Zeus, Boreas, Poseidon, the Hindu deity Many armed Shiva and the Slavic pagan Perun, Stribog: Боги Еллади задля злого жарту На кін кидають блискавку і грім. А ми собі шукали биту карту, Аби роздати козирі усім [14, p. 72]. Adjacent to paganism are genitive constructions: (god) of war, fire, people: Що весіллям було - / Обертається тризною, / Льодовий апокаліпсис / Бога вогню... [9, p. 39]. The similarities and differences between the Christian God and the pagan gods are reflected in the comparison of the lexems God / god (gods). The first image in contexts embodies a higher personified force that has power over man or some branch of his existence and faith in which is fueled by 
modern religious practice (the institution of the church, theology, etc.), and the second exists as a memory of the word, not without the influence of pagan culture. This difference is manifested in orthography (large and small initial letters), grammar (the use of the word-concept of God only in the singular) and at the lexical level due to extralingual factors.

Thus, most of the identified conceptual meanings, common in general language practice testify to the positive connotation of the concept-image of God. He is the bearer of non-predicative qualities that emphasize the attributes of holiness, such as: My God supreme, Most Holy, righteous, great, merciful, forgiving - and predicative signs: "Той, який прощчає», «Той, якого восхваляють, якому моляться», sometimes ambivalent («Той, який творить» / «Той, який руйнує»; «Той, який оберігає, рятує, допомагає» / «Той, який карає»). Also established onyms are those which, expanding its nominative field, explain mythopoetic and profane, purely folk, ideas about God: formidable, old, God of the proto-Ukrainian steppe, such as: а з лугів виглядаю вчорашнього Бога [9, p. 203]; we also record occasional use - Може, бог наш до нас поспішить? / Може, бог у єдинім: добігти? [9, р. 340].

The specificity of the linguistic representation of the concept is represented by the actual poetic semantic individual-authorial and expressive-pictorial properties in poetic speech. They are attested in the diversity of derivational structure of words that come from the main lexical verbalizers of the concept and can be traced primarily in attributive constructions: divine (woman, garden, temple, name, night, soul, forehead; goddesses (Ukraine, beloved, words); God's wounds are unhealed; crazy summer, the God's summer, in symbolic and metaphorical structures (the God's voice, the God's eye, the God's ear, the chariot of God), in individual authorial periphrastic and comparative constructions (Земля - Божий камінь; Як юний бог, як молодий гульвіса // Я йшов, всі ми були як богове; жінка - Скрипка Бога, жінка - наче квітка Бога), sисh as: любив ичю божественну жінку. / Я возносив тебе до зірок [13, p. 70].

\section{Linguistic representation of the images of the Son of God and the Mother of God}

Another of the main characters who define the essence of the sacred, according to Christian tradition, are the Son of God and the Mother of God. 
Jesus Christ is the center of the Christian religion, a universal conceptimage, which is at the same time the most complex, because it embodies the features not only of God but also of a perfect man endowed with extraordinary morality, spirituality, ie ideal in its basis. It is allegorical and autological at the same time. The core of this earthly incarnation of the deity is the name itself, which includes the essence of the whole set of plots - Jesus Christ, God the Son, the Son of God, the Messiah, the Godman, the Savior of mankind, the Crucified Son.

The Greek word Christ, meaning Messiah, means the title "anointed one" The epithet "anointed" was used in ancient Israel in relation to prophets, priests and kings [19, p. 796]. According to Christian teaching, Jesus Christ is the Messiah, Savior and Redeemer of mankind from the yoke of sin, God the Son in the Holy Trinity. The syncretism of the concept-image of the Son of God allows us to consider Him not only from the standpoint of the central figure of the Bible, but also can be presented as a scenario of earthly life, for example: Gospel story of Christ's life on earth: birth, spiritual growth , death, and then resurrection, service in heaven. Organic for the conceptual unit God context environment contributes to the appropriate implementation of the conceptual component of the concept of Godman: in poetry allusions to the New Testament history from the Immaculate Conception unfold [12, p. 31] and the joys of birth - Божий син народився, $і$ чути в вертепу / Богорівні, спасенні, великі слова... [9, p. 133]. The author proposes a kind of genealogy of Ukrainians, which, according to his assumption, has a divine origin: Мu dimu Meciï ŭ Tapaca [9, p. 60]. The plane of faith is united with the plane of the real past of Ukraine by the poetic comprehension of the poet's role in Dmytro Kremen's artistic pursuits: the sacrifice of the Son of God for the salvation of mankind and the poet's sacrifice for the sake of his native country. A visual ethno-nationally connoted image is formed: лівесенько де серие у поета / червона мітка крові / це деталь / а хрест а тінь Месї̈ розіп'ята / сорочка біла і червоні маки [9, р. 122]. То believe in God means not only to believe in his existence, but also to give oneself completely to him, to live according to his laws: Але тому боговілюдині, / Що до нас прибув із небесі, / Все життя віддати по краплині / Чи не ми клялися з вами всі? [9, p. 47]. In the poem «Benefit on Golgotha» D. Kremin sarcastically draws parallels between the condemnation and crucifixion of Jesus Christ and the spiritual execution of the poet in Ukraine. 
The national components in the structure of this concept are associatively connected with the interpretation of God the Son as a victim of the Soviet regime: in the sacred 33 years Hrytsko Chubai left us («і мені з небесі вже махає рукою / вже за мене молодиий Грииько») [9, p. 326]. Fate is not always kind to a morally perfect, true man, who is the bearer of Christian and, consequently, moral values, which were imitated by the poet's friends, and which the author himself tried to adhere to: Прозирати і нам довелось / У безодню неволі і чести, / Де хреста украйнський Христос / На Голготу не може донести [9, p. 307]. Although the author notes that "рівнятися із Господом - негоже», however, he embodies himself in the shadow of God: «Я тінь Твоя, І я в твоїм сліду» [9, p. 20]. And when he says at the beginning that they "розп'яли обох», it is also a hint that the verse will not only be about the crucifixion of Jesus Christ.

The moment of execution-resurrection of the martyr is also represented through the foreseen moments of sacrifice, redemption and wider salvation restoration - renewal, the main conceptual meanings of this concept-image. The expression to descend from heaven to earth has a usual meaning "from dreams to return to reality", and in the poetic text there is a literalization of the meaning of phraseological inversion and the original, direct meaning of the connection is not only actualized but also comes to the fore, often opposing the established meaning of the expression.

The writer demonstrates the unusual contamination of realistic and biblical plans by introducing into the paradigm of meaning the Son of God (one of the three incarnations of the one true God) the conceptual meaning of God is the Hope for the salvation of Ukraine: Боже, як ще не покинув нас ти, / На украӥнському вічному небі / Божому сину зорю засвіти! [9, p. 331]. In poetry, Jesus Christ is associated with security, visible prospects for happiness: Як нам дочекатися Месї / На замерзлі наші береги?.. $[1$, p. 171]. The next stage of change in the conceptual component of the concept of God is manifested in our time, when «Donbass is burning», and only God is the Hope for liberation: I лии Божсий Син / Визволить усіх [13, p. 31]. Two years «Ukraine in camouflage» - and the poet aches: Чи поміж нас не виростуть чужі - / Боги й богове, перуни й стрибони? [13, p. 8].

Derivatives in the name of Jesus Christ have a narrower meaning, emphasize only one feature and draw parallels with one episode of biblical history, eg: Jesus is a child of God: Icycuк [9, p. 144]. 
The artist assigns an important place in poetic texts to the Mother of God, who at all times was the personification of spiritual purity, great maternal love. According to Christian dogma, Mary is the Queen of Heaven, the Mother of the Son of God, who conceived and gave birth to him immaculately to fulfill the divine plan of salvation for mankind and for all Christians. Such is the view of the Supreme Spiritual Being in Christianity, where the activity of God and after the creation of the world is seen in the loving care of the world and people.

The main conceptual meanings realized in the structure of the concept in poetic texts are: motherhood verbalized in the names Mother of God, Mother of God, the Virgin, Madonna, such as: Мадонна народить / Нам Месію в журбі молодій [10, p. 148]; The Virgin is represented as the Virgin, the Virgin Mary, the Immaculate (Immaculate, Most Holy) Virgin: Пречиста діва [13, p. 196], Діва Марія [1, p. 51]; intercession, patronage - Our Lady of Mary Oranta, Mother of God, eg: Божа Мати, візьми під покрови, / не мене, а забуте село [10, p. 126]. I. Bereza, analyzing the image of Our Lady Maria Oranta in the poem of the same name with the note «Sophia of Kyiv. XI century» [1, p. 96], noted that the Mother of God, embodied in a mosaic canvas in the image of Oranta - is also a «path to God» In the question of the poet - our contemporary - to the patroness of the Mother of God, the defender of Ukrainians, painful Shevchenko's notes are learned» [2, p. 12]; an image-miracle, which is an individual author's meaning: ...людям забаглося чуда: Божа Мати стоїть у вікні! [1, p. 126].

The high spirituality of the Mother of God and her motherly vocation are revealed by the attributive nominations of the Righteous, the All-Merciful, the Most Pure, and the Most Holy. The author places a semantic emphasis on the innocence of the Mother of Jesus Christ, using in her definition substantivized adjectives with Old Slavic prefixes pre- and vse-, which indicate the highest degree of sign.

The complexity and multifaceted nature of Kremen's understanding of the image of the Mother of God is most fully manifested in the poem "Anno domini. The Missing Poem», which synthesizes canonical and non-canonical conceptual elements, which brings this sacred concept closer to the profane, while desecrating the mystery of the Savior's incarnation: А ї називають Марія, / По-біблійному звуть [9, p. 143]. Mary is the embodiment of the image of a biblical sinner, a priestess of beauty, a bacchante: $A$ i 
називали - Марія./ Не на панщині жала вона, / То й месію в собі заморила / Від саке, від горілки і вина. / Ні Ісусика, ані Тарасика [9, p. 144]. At the same time, she embodies a Ukrainian woman: Дe Mapi, Марія, Україна? Темна ніч, а кажуть нам: десь $\epsilon$ [9, p. 151].

In Kremen's poetry, a woman becomes a goddess, and the Mother of God becomes an earthly woman, a mother: Із хати вийдеш. Виб'єш килими, / Із ликом богоматері сумної... / Останньої біблійної зими - / Останній сніг на білому сувої [9, p. 81]. In another context: Ти мені й по смерті будеш мила. Ти мені всю душу полонила, / Жінка із очима божества [14, p. 56], where the deity, according to Christian sources, is a being of God «неизглаголанное, непостижимое и никакому точному изсльдованію и описанію неподлежащее» [19, p. 55]. Therefore, for D. Kremen, the beloved is the deity he exalts «до місяия й зір» [14, p. 18].

\section{Sacred conceptual lists of other biblical microgroups}

The first step of the Celestial Hierarchy is occupied, according to lexicographical sources, by seraphim - forces of the highest rank, which were depicted with six wings [19, p. 237]. The third step - archangels and angels. Archangels are considered higher and more powerful than angels. There are nine of them. Among them are three archangels - Michael, Gabriel and Raphael. The first to rule over the heavenly angelic forces is the archangel of God's justice, judgment, grace, and mercy, who is considered one of the strongest heavenly spirits. Gabriel is considered a good announcer, because it was he who brought the news of the birth of Jesus Christ: Архангел Михаїл. Собор Бориса й Гліба. / Видовищ даждь нам днесь. А там вина і хліба [9, p. 23; 13, p. 19]; архангели Гавриле й Михайле [13, p. 68]. We record the use in the form of Michael the Archangel, where the Archangel - the military leader [19, p. 25]: А ия зима - немов сторінка біла. / А вежа серед степу - золота. / Крило архістратига Михайла / До нас у Дике Поле заліта [9, p. 87].

The spiritual invisible world, or the world of angels, ie messengers, whom God sends to announce His commands, is presented in the branched verbalizers of the concept-image - angel, angel: as a Christian "supernatural being": Зіграє ангел на небеснім горні [9, p. 11]; as an ethnocultural «character of the ancient mobile Ukrainian puppet theater»: Відкривайся, грайся, мій вертепе - / Янгол, чорт, лихвар і офіцер [9, p. 159]; as «a person who 
is distinguished by beauty or kindness, gentleness or has done or is doing something good, pleasant to someone» in individual-author use: Замовкла наша коляда/ Без янголів письменницької спілки [9, p. 154]. The author endows the concepts-images with anthropomorphic features, desacralizing them at the same time: Зомліс ангел [9, p. 158]; бідний янгол [9, p. 14].

In the poetic idiosyncrasy we fix derivative formations, among which derivational correlates: the diminutive formation янгол - янголятко; янголи - янголята, ангели - ангелочки: Янголятко любе, ти 3 Почайни / Знову хрест на дрова понесло? [9, p. 108]; attributive nouns: Архангельська труба [13, р. 68].

Instead, in the poetic works of D. Kremen in the structure of these concepts are conceptual meanings that represent the Christian hierarchy of good and evil angels (devil, Satan), who rebelled against God, lead people to sin. Verbalization confirms the conceptualization of Celestial Beings as ambivalent and contains a negative connotation: Янгол смерті з дитячим лищем [9, p. 339].

Thus, we can talk about the development of the conceptual content of the lexems God, Jesus, the Virgin, angel, etc., the emergence of new conceptual components associated with the synthesis of canonical and non-canonical conceptual elements, bringing these sacred concepts with profane, often desecrating, revealing a deeply organic combination of national worldview and individual understanding of the factor of involvement in God through the principle of God's presence (triad theocentrism -anthropocentrism ethnocentrism as a universal formula of the sacred universe and worldview).

Biblical prophets (biblical Greek $\pi \rho \circ \varphi \eta \tau_{\varsigma}$ ) mean, firstly, a person who foresees the future, an announcer of God's Will, and secondly, a person who announces the word of instruction, instruction and consolation through the inspiration of the Holy Spirit [19, p. 512]. The biblical prophets saw the development of mankind many thousands of years ahead and spoke on behalf of God about God. Concepts-images of prophets are presented both by common names and proper: Isaiah, Hosea, John. Along with other lexical resources, they create a powerful emotional field that surrounds the text, saturated with metaphorical imagery with a positive or negative connotation: Пророк...Ти схилив сумовите чоло [9, p. 338].

Desacralizing, D. Kremin also uses poetonyms: the prophets John the Baptist (John the Baptist, John [19, p. 238]), Elijah - the most revered saints in both the Orthodox and Catholic churches: на колісниці між зірок 
одкрив планшет Ілля-пророк [14, p. 8]; Isaiah is a great prophet because he wrote the Book of the Prophet Isaiah, which theologians call the "Little Bible," and Hosea is a lesser prophet because he left behind fewer prophetic books than the great prophet, but the poet declares: Чи Осія мені, чи Ісайя, - Все одно мені, ох, все одно [14, p. 38]; Moses - a prophet, leader and legislator of the Jewish people, the first holy writer [19, p. 313], mentioned in the comparative construction: Ходиш, мов пустелею Мойсей, / Сорок літ - і все кінияя немає [9, p. 17].

In D. Kremen's artistic picture of the world, the lexical representation of the microconceptosphere "biblical characters" may coincide with its verbalization in the religious picture of the world. The name of magi learned men, sorcerers, magicians - acquired a high poetic sound. These sages are often depicted as kings in Christianity. Three kings, named in apocryphal sources Caspar, Melchior and Balthazar, who foretold the birth in the East of the Savior of the World of the Future, came to the baby Jesus [19, p. 92; 3, p. 133]: I там, де скрижалі епох золоті, / I там, де три царіє із дарами, / Нас порятують хіба щзо святі, / Що в люди пішли, покинувши храми [8, p. 354]. Magi are powerful people; which is given a lot. Adding new words leads to semantic change, providing additional information and symbolization: Загорілися букви в небесній книзі, / наче знаки волхвів віфлеємських... / Загорілися небо й земля... [9, p. 321-322].

The structure of the concept «apostle» actualizes sacred conceptual meanings: non-religious «ardent follower, passionate defender and preacher of a doctrine, ideas, value systems» and Christian «disciple of Jesus Christ, chosen and sent by Him to preach.» In D. Kremen's poetic idiosyncrasy the images are desecrated: Апостол на пенсіі. / Садить огород [9, p. 112]; or in another context where the holy apostles Peter and Paul are mentioned: Голодує Петро на Хрещатику, / Під хрестом у Петрівку - Павло... Переходять у міф і легенду / Петя з пломі, а з храму - Павло... / А любили ж ви мамині яблука / У дитинстві, Петро і Павло... [9, p. 85]. Mentioned in the author's idiosyncrasy, both Orthodox and Catholic saints - St. Nicholas, St. Sebastian: I прилине святий Миколай / Воскресити зорю з-за туману [9, p. 44]. To a lesser extent, such biblical concepts-images as Herod, Judas, Abel, Cain are represented, eg: Xmo вірить - не вірить. / У вертепі -мла... / Хижо глипає Ірод [14, p. 62]. 
The biblical names Cain and Abel actualize sacred conceptual meanings such as Cain - «criminal», «murderer», and Abel - «innocent victim» [9, p. 28-29]. When using a conceptual image-symbol, there is a destruction of established meanings: I побивається за Каӥном / Убитий Авель, чи не так? [8, p. 29]. In D. Kremen's poetry there is an expansion of the semantics of component composition, play of images and concretization of meanings. Cain gets the following additional meanings in context: these are those who exterminated their people - «Stalin and Beria, Hitler», Abel the embodiment of a slave, a serf who «feels sorry for the master.» In the context of the poem «One epoch is gone» we record: Світило - Місяиь, $i$ брати / Вже натрудились - Авель, Каїн [13]. Modernity, when there is a «war. Hybrid and cunning «, makes its own adjustments in the interpretation of the images: Здіймає Каӥн Авеля на вила. / На Місяиі./ Я бачу изе щзодя. / Щовечора...[13, p. 55], which are not completely detached from the original value: І знову - на батька син і брат на брата? [13, p. 55].

The artist, preserving universal symbolism, in the structure of the concept of Adam complements it with national receptions and individualauthor interpretations: Доживемо до другого потопу? / Хто нас врятує Дант, Орфей, Адам? [9, р. 28]. Active in the poetic work of the artist is the image of Adam's land, which carries the tragic meaning of «lost land», the image of which correlates with the Silver Land, creating a lexical antithesis: spiritual greatness and fate: Ти звав ї Адамовою? Ні. Вона пребуде Срібною Землею [8, p. 26].

Purely sacred are a microgroup of concepts «biblical loci»: heaven, hell, heaven, that world, this world, the Garden of Gethsemane, Eden, Jordan, еtс.: Господи, спаси, не забирай / Украӥнський мирний, тихий рай [14, p. 17]. In the work "Black Mass", the transformation takes place through an antonymous change in the component composition of Dante Alighieri's statement, the first circle of Hell: Перше коло едему, - це близько. I Та вогонь - уже в тиші німій - / Видирають із рук василіски [10, p. 338]. The sacred conceptual meaning of Eden is actualized, the gardens of Eden are a synonym for the words «paradise», «heavenly life».

Among sacred onomastics a special place is occupied by precedents of toponyms as models that actualize prototype situations and are translators of knowledge about the world. Thus, the biblical Royal Gates symbolize the gates of Paradise and mean that Jesus Christ entered through them in the 
Holy Gifts: Гарбузова доля в нас щерббата, / Без ичаря, поблизу ичарських врат [9, p. 186]. In the biblical expression of Sodom and Gomorr, where the two cities of the Middle East are named, which incurred the wrath of God by defects and atrocities, the sins of the people who lived there, the replacement of the component of Gomorr by violence is due to the meaning of the component as "disorder, chaos": Дай нам часу грибного завзяття, відпусти / нам гріх - содом і гвалт [13, p. 45]. The Jordan is known in sacred (biblical) history as a river that parted to give passage to the Jews, and as a place where John the Baptist preached and Jesus Christ was baptized [19, p. 237]. The poet means a Heavenly Jordan [9, p. 171].

The poet interprets the actual sacred conceptual units, which unite in the group "church organization and cult". They serve as a means for him to rethink eternal questions, allow him to delve into the essence of important things: Пане Боже, звістую про Книгу Буття. / Аз єсьм раб твій, i трапеза - мед $i$ кутя / Не в монаха, а в мене. Мій жезл $і$ офіра... $[14$, p. 18]. Thus, various concepts of religious buildings and their parts were discovered - church, temple, cathedral, chapel, altar, wing: I деcь у Плеядах - зоря над свічадом лиману / Й московської віри останні козащьькі ичеркви [3, p. 33].

One of the components of traditional nominations is the name of the church hierarchy, ie clergy and ministers, church positions, church organization: bishop, patriarch, monk, priest, abbe (father), panotche, metropolis: Панотець - комуніст а чи юда [1, p. 126]. The group is supplemented by the names of the elements of church services, sacraments and rites: baptistry, canon, christening, prayer, meal, anathema, etc.: I картина ияя уже остання.../ Душу відпусти на покаяння! / Щоя знаю? Славу? Слава-дим $[14$, p. 55]. Prayer as a "reverent word to God" for the lyrical hero often takes the form of worship, praise, request I во ім'я Отия / I во ім'я розпятого Сина [13, p. 59] or simply the presentation of his thoughts: Став я співцем віфлесмських зірок. / Став на коліна в молитві, у требі [9, p. 331]. For the poet, «turning to God became an obvious way of finding oneself in difficult life conflicts, and Christian ethics - a measure of spiritual worldview, the continent of further artistic development» $[15$, p. 23], a source of individual authorial meanings: Господи / молюсь тобі сльозою... [12, p. 34].

To the group of names of elements of church sacraments and rites we include symbolic names: bread is the body of the God: I тіла хочу, мов 
біблійний хліб, / I голосу, спасенного романсу... [9, p. 81]. Attributes of objects of worship related to church and ritual activities, priestly armor are verbalized in the names: cross, image (face), icon, lamp, candle Прозирає з розтерзаних стін / Візантійськими ликами святість [9, р. 307]; номенах мирро (застаріле мірро), єлей, кадило - коли засмучений пророк уже подався до зірок / $i$ понесли у мавзолей прогірклі мирро і єлей [14, p. 8]; names of clothes of priests-golden shirts $[14$, p. 58]. The sacred world of D. Kremen's poems is complemented by the names of liturgical books and their parts: the Bible, the Book of Genesis [14, p. 18]: На крилосі біблію розкрию, Прочитаю вічні письмена.

The conceptual group "sacred time" consists of the names of the church calendar, church holidays: Christmas, Annunciation, Honey Savior, such as: And this land is not to blame, / That the Honey Savior passed here. I And the music of the holiday cries, / And the music cries for us... [9, p. 176].

The nominative set of concepts for the definition of moral and ethical names is the vocabulary of Christian morality, including reactions related to the spirit, spirituality - goodness, soul, love, and violation of religious and moral principles - sin, sinful, wicked, the interpretation of which covers a number of individual - author meanings: На світі немає провінцій / I є іше космос душі [1, p. 137].

Motives, images and plots of the Book of the Holy Scriptures help to understand the vicissitudes ofUkrainianmodernity. The works ofthecollection are characterized by a keen sense of the Fatherland, a deep awareness of the artist's responsibility to God and the people. Phraseologisms connected with biblical motives are an effective component of the conceptosphere "sacred", because the possibilities of forming expressive-emotionalevaluative connotations of the phraseological system are much greater than the lexical one: punishment (of God), way of the cross, resurrection, crown of thorns. The special imagery of any expression is modeled by the original combination of concepts formed as constant associative realities, ie as verbal images-symbols, which is the result of conceptual rethinking of objects and phenomena: Як є ти, Боже, праведний, великий / Дай $i$ мені тернового віния («Золота брама»). According to ancient custom, the convict carried his cross to the place of execution; The biblical cross symbolizes the hope of salvation:... Де хреста украӥнський Христос / На Голготу не може донести [9, p. 307]. The phrase «bear your cross» is 
also known as «patience, difficulty; the difficult path to the set goal», «the way of the cross» [1, p. 144] - the essence of human existence, full, on the one hand, high and sublime, on the other - everyday-earthly: Українське слово буде з нами / На Голготу йти, і йти, і йти, / I каміння, $і$ хрести з орлами, / I на скромних пагорбах - хрести [9, p. 236]. «Pray for sins» - to atone for your sins with prayers, actions: О жінко, дамо серия, / в однині / гріхи замолим, а мізки припудрим [8, p. 123].

Using allusion in context: Сад Гетсиманський. Коло хати / Хрущі травневі не гудуть [9, p. 30], the author expects the presence of certain background knowledge in the reader, and s ubject to a successful process of decoding allusions, the reader receives a large emotional charge for mental work. Some of the analyzed concepts are recorded in the titles of the poems "Cathedral», "Cathedral in the middle of the universe», "Christmas in Bogopol», «Southern Cross», «Mother of God in the snow» and the title of the collection «Lampada over Sinyukha».

The world of sacred-chthonic beings, evil spirits, verbalized in the nouns of Satan, demon, devil, serpent, is axiologically opposite to the world of God, testifies to the author's rejection and denial of their intrigues, is for him a means of rethinking eternal questions and eternal choice: I хто нас maм жде? / Сатана / Чи знаки від Бога? [14, p. 23]. The main components of the meaning of the words Satan, devil, antichrist and others - «evil», «meanness», «betrayal», «cunning», «misfortune», «death». In a broad abstract sense, the devil (Satan) is an expression of the idea of the finiteness of all things: Диявол усміхається нечасто / але завжди він криється в деталях / у ичифрі й блиску срібної каблучки [8, p. 40]. The original form of the permanent expression serpent-tempter - the most cunning and insidious of all God-created creatures («snake-tempter» - in the Church Slavonic language) - by partially replacing the lexical component takes the form of serpent-seducer: Змій-облесник в райському саду... [9, p. 177]. In another context: Зі стін промовляють улесливі 3мії [13, p. 32]. Noticing the signs of dichotomy in the lyrical hero as a characteristic feature of national identity, the author confirms that sooner or later they could lead to great trouble ( $« \mathrm{I} \mathrm{am}$ both a demon and a god...»), so D. Kremin sadly notes that «загубилось між зір і епох / I моє покоління» [8, p. 61]. The worst that surrounds a person brings him suffering, misfortune associated with these images: Кажани між стропил прижсились Украӥнському хитрому чорту [1, p. 66]. 
A special group in the system of conceptual units are words like amen, hallelujah, hosanna. Thus, in the use of biblical Hosanna (literally: «save!»); In its original meaning, "the prayerful cry of the ancient Jews and Christians»; "glorification of someone, something; glory, praise» [3, p. 421] in the context of I- осанна хмільному вину наших літ. / I- осанна вікну, що прочинене в сад $[9$, p. 312] we record a violation of the subject-logical distribution. It occurs due to the departure from the semantics fixed by the language usage, «redirection». Combinations sing hosanna («praise, praise») in the lines I співають осанну невисохлі ріки. / Отче наш на землі і на небі [9, p. 304] characterizes both the behavior and the emotional state used in relation to non-beings.

\section{Conclusion}

Most of the concepts of the sacred sphere are not an ordered, obvious set of realities, but a synthesis of abstractions, and not universal, generally accepted, but individual, created mostly by the native speakers' own imagination. Most of the original, often unexpected associations were found in the objects, which were characterized by exceptional significance, special value and therefore caused respect. In-depth linguistic study requires establishing the ratio of common language and mythopoetic meanings of individual concepts-images in poetic texts and analysis of distributive and derivational features of verbalizers of these concepts in the poet's idiosyncrasy, which will help to identify not only the meanings of the analyzed concepts, but also ethnopsychological, linguistic and cultural principles of national perception and understanding of conceptual semantics.

\section{References:}

1. Antoniuk A., Kremin D. (2007) Lampada nad Syniukhoiu : albom-antolohiia / khudozh. A. Antoniuk [Lampada over Sinyukha: album-anthology]. Mykolaiv: Atol, 215 p.

2. Bereza I. Yu. (2013) Zorovi obrazy sakralnoho svitu D. Kremenia [Visual images of the sacred world of D. Flint]. Naukovi pratsi. Literaturoznavstvo Mykolaiv: Vyd-vo ChDU im. Petra Mohyly, vol. 212, tom 224, pp. 11-14.

3. Bybleiskaia entsyklopedyia [Biblical encyclopedia] / sost. arkhymandryt Nykyfor (Bazhanov). Reprynt. yzd. 1891. Moscow: TERRA, 1990. 903 p.

4. Vilchynska T. (2008) Kontseptosfera sakralnoho v suchasnii naukovii paradyhmi [Conceptosphere of the sacred in the modern scientific paradigm]. Teoriia i praktyka vykladannia ukrainskoi movy yak inozemnoi: zb. nauk. prats. Lviv, vol. 3, pp. 150-159. 
5. Vilchynska T.P. (2009) Rozvytok kontseptosfery sakralnoho v ukrainskii poetychnii movi XVII-XX st. [Development of the conceptosphere of the sacred in the Ukrainian poetic language of the XVII-XX centuries]: avtoref. dys. ... d-ra filol. nauk: 10.02.01. Kyiv, 38 p.

6. Eliade M. (2000) Sviashchennoe y myrskoe. Elyade M. Myf o vechnom vozvrashchenyy [Sacred and secular. Eliade M. The Myth of the Eternal Return] / perevody s frants.; nauch. red. V. P. Kalyhyn, Y. Y. Sheptunova. Moscow: Nauch.issled. tsentr «Ladomyr», pp. 249-356.

7. Kovtun A., Skab M. (2010) Mizhnarodna naukova konferentsiia «Ukrainska mova i sfera sakralnoho» [International scientific conference "Ukrainian language and the sphere of the sacred"] (21-23 zhovtnia 2010 roku, Chernivtsi). Ukrainska mova, no. 4, pp. 116-121.

8. Kremin D. (2011) Zamurovana muzyka: liryka, symfonii, poemy [Bricked music: lyrics, symphonies, poems] / peredm. V. Bazylevskoho. Kyiv: Yaroslaviv Val, $360 \mathrm{p}$.

9. Kremin D. (2001) Elehiia troianskoho vyna [Elegy of Trojan wine]. Mykolaiv: MP «Mozhlyvosti Kimmerii», 105 p.

10. Kremin D. D. (2003) Litopys [Chronicle]. Mykolaiv: Mozhlyvosti Kimmerii, 452 p.

11. Kremin D. (2014) Medovyi misiats u Karfaheni: vybrani virshi ta symfonii [Honeymoon in Carthage: selected poems and symphonies]. Mykolaiv: Ilion, $252 \mathrm{p}$.

12. Kremin D. (2006) Poliuvannia na dykoho vepra [Wild boar hunting] / uklad. V. Herasymiuk. Kyiv: Molod, 94 p.

13. Kremin D. (2016) Skrypka $\mathrm{z}$ toho bereha: liryka [Violin from the shore: lyrics] / uporiad. T. D. Kremin ; khudozh. Yu. S. Humennyi. Mykolaiv: Ilion, 88 p.

14. Kremin D. (2014) Slozy Sukhoho Fontanu: liryka [Tears of the Dry Fountain: lyrics]. Mykolaiv: Vydavets Shamrai P. M., 72 p.

15. Kremin T. D. (2009) Metalohichna retseptsiia Boha v lirytsi Stanislava Misakovskoho i Dmytra Kremenia [Metalogic reception of God in the lyrics of Stanislav Misakovsky and Dmitry Kremin]. Naukovi pratsi ChDU im. P. Mohyly. Filolohiia. Literaturoznavstvo, no. 5, pp. 22-26.

16. Maslova V. A. (2004) Kohnytyvnaia lynhvystyka: ucheb. posobye [Cognitive linguistics: textbook]. Mynsk.

17. Nabytovych I. (2008) Universum Sacruḿu v khudozhnii prozi (Vid modernizmu do postmodernizmu) [Universum Sacrumu in fiction (From modernism to postmodernism)]. Drohobych-Liublin: Posvit, $600 \mathrm{p}$.

18. Nabok-Babenko Yu. S. (2013) Bibliini motyvy ta obrazy u zbirtsi dmytra Kremenia «Pektoral» [Biblical motifs and images in the collection of Dmitry Kremen "Pectoral"]. Naukovi pratsi. Literaturoznavstvo. Mykolaiv: Vyd-vo ChDU im. Petra Mohyly, vol. 210, T. 222, pp. 31-34.

19. Polnyi tserkovno-slavianskyi slovar: (so vnesenymi v neho vazhneishykh drevne-russkykh slov y vyrazhenii) [Complete Church Slavonic dictionary] sost. sviashchennyk mahystr Hryhorii Diachenko. Moscow: Typohrafyia Vylde, 1900.1120 p.

20. Relihiieznavchyi slovnyk [Religious Dictionary] (1996) / za red. profesoriv A. Kolodnoho, B. Lomovyka. Kyiv: Chetverta khvylia, 392 p. 
21. Selivanova O. (2008) Suchasna linhvistyka: terminolohichna entsyklopediia [Modern linguistics: terminological encyclopedia]. Poltava: Dovkillia-K, 712 p.

22. Skab M. V. (2008) Zakonomirnosti kontseptualizatsii ta movnoi katehoryzatsii sakralnoi sfery: monohrafiia [Regularities of conceptualization and language categorization of the sacred sphere: monograph]. Chernivtsi: Ruta, $560 \mathrm{p}$.

23. Shevchenko V. M. (2004) Slovnyk-dovidnyk z relihiieznavstva [Dictionaryreference book on religious studies]. Kyiv: Naukova dumka, 560 p.

24. Sawicki Stefan (1980) Sacrum w literaturze [Sacrum in literature]. Lublin: Towarzystwo Naukowe Katolickiego Uniwersytetu Lubelskiego, T. XXVIII. Z. I., pp. 13-26. 